\title{
陳旧性肩関節脱臼に対し観血的治療を行った例の経過
}

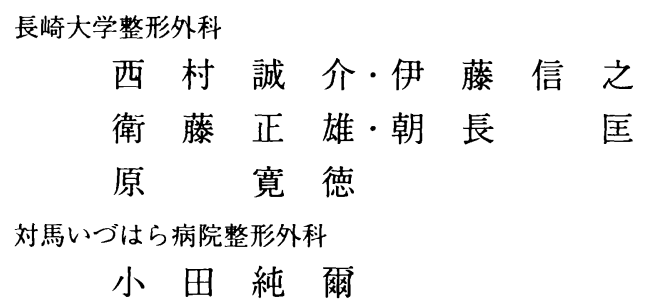

\section{Follow-up Study of Surgical Treatment for Chronic Unreduced} Dislocation of the Shoulder

by

Seisuke Nishimura, Nobuyuki Ito, Masao Eto, Tadashi Tomonaga and Hironori Hara

Department of Orthopaedic Nagasaki University School of Medicine, Nagasaki, Japan

\section{Junji Oda}

Department of Orthopaedic Surgery,

Tsushima Izuhara Hospital Nagasaki, Japan

Dislocation of the shoulder is difficult to reduce when it has been a long time since the initial dislocation.

We reviewed the results of surgical treatment in 4 patients with 4 right shoulders that hadn't been reduced. Their ages ranged from 30 to 70 years with an average of 51 years. The duration of the dislocation was between 6 weeks and 56 weeks, with a mean of 22 weeks.

Glenoplasty was attempted in 3 cases, and Total Shoulder Replacement in one case. The case with TSR was dislocated a few days after surgery and it was removed because of infection.

Assessment based on function or JOA score did not demonstrate such a good result. However, their ADL did improve.

Key words : Chronic Unreduced Dislocation of the Shoulder (陳旧性肩関節脱臼), Open reduction（観血的整復）

$$
\text { はじめに }
$$

肩関節脱臼は発見が遅れると陳旧化し, 整復は困難 となる。また，整復位を得られたとしても可動域の改 善は得られにくい.このため治療に関しては保存療法 から観血的療法まで多くの意見があり，未だ治療方針 は確立していないのが現状である。当科では 1997 年 5 月までに 4 例の陳旧性肩関節脱臼を経験し，観血的
治療を選択してきた．今回この 4 例について経過を調 査し, 観血的療法の有効性を検討したので報告する.

\section{対象および方法}

対象は 1984 年より 1997 年までに経験した陳旧性肩 関節脱臼 4 例， 4 肩関節で全例右側であった。性別は 男性 2 例, 女性 2 例で手術時年齢は 30 から 70 歳で平 均 51 歳であった。脱臼を起こしてからの期間は 6 か 
ら 56 週で，平均 22 週経過していた，術後の観察期間

は 7 カ月から 12 年 9 カ月であった。

このうちの 3 例では, 久損した関節䆚に骨移植を行
い, 1 例では人工肩関節置換術を行った。

これらの症例に対し，局関節疾患治療成績判定基準 （以下 JOA score）を用いて評価を行い, 結果に影

(点)

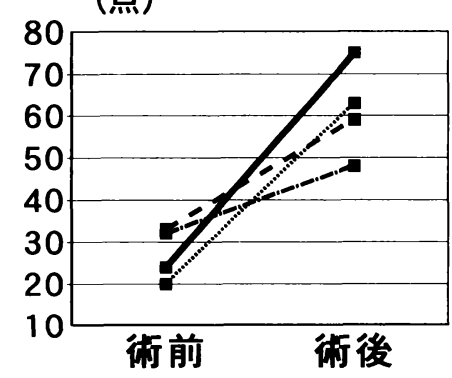

\begin{tabular}{ccc}
\hline 症例 & 術前 & 術後 \\
\hline 1 & 24 & 75 \\
2 & 33 & 59 \\
3 & 20 & 63 \\
4 & 32 & 48 \\
\hline & & (点)
\end{tabular}

图 1 JOA スコアの変化.

各症例の最終観察時 JOA score は症例 1，2，3，4それぞれ 75 点，59 点， 63 点, 48 点であった.

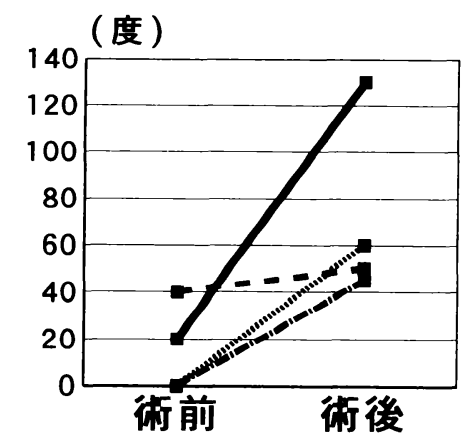

\begin{tabular}{ccc}
\hline 症例 & 術前 & 術後 \\
\hline 1 & 20 & 130 \\
2 & 40 & 50 \\
3 & 0 & 60 \\
4 & 0 & 45 \\
\hline
\end{tabular}

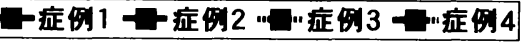

(度)

図 2 屈曲角度の変化.

症例 1 で大きな可動域改善が見られたが, 他は若干の改善があるのみであった.

(点)

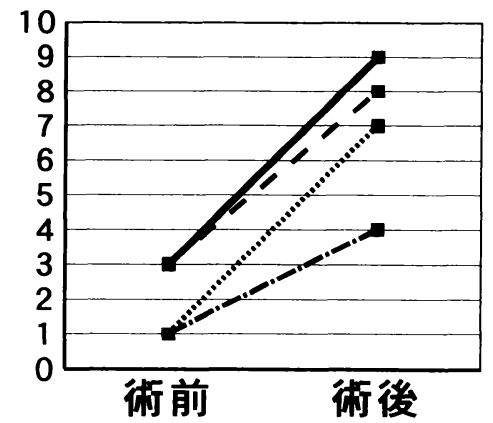

\begin{tabular}{ccc}
\hline 症例 & 術前 & 術後 \\
\hline 1 & 3 & 9 \\
2 & 3 & 8 \\
3 & 1 & 7 \\
4 & 1 & 4 \\
\hline & \multicolumn{3}{c}{10 点満点 }
\end{tabular}

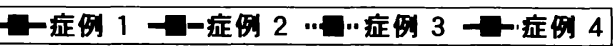

図 $3 \mathrm{ADL}$ の変化 (JOA score 日常生活動作群による採点).

関節窝形成術を行った 3 例では術後可能動作が増え，患者も满足していた. 


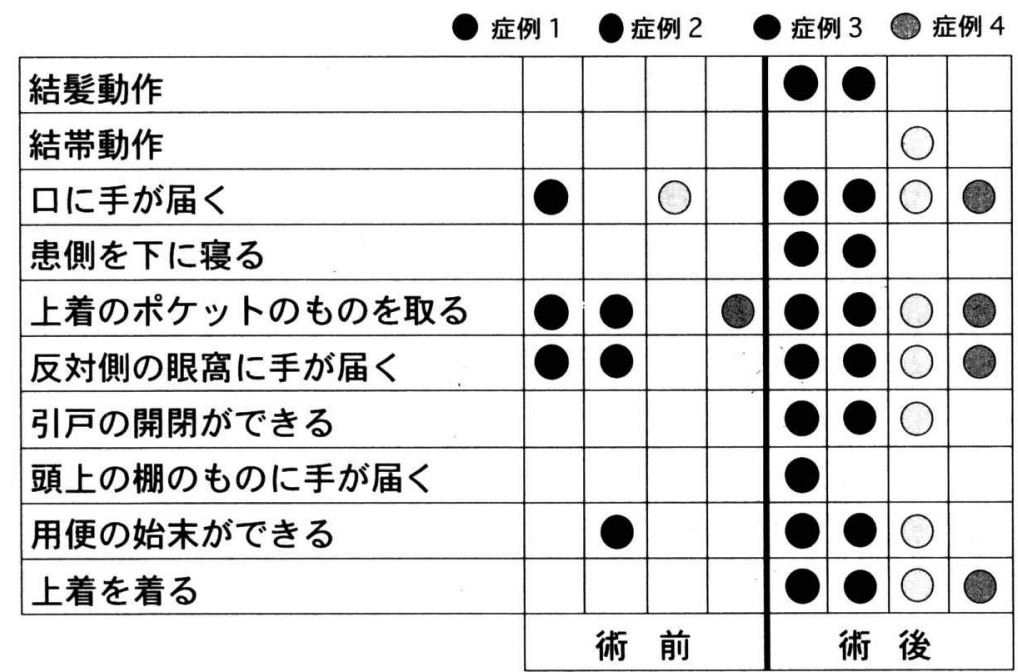

図 4 術前および術後の ADL の詳細.

全症例で術後に可能動作が増えた。○はその動作が可能であることを示す.

響を与える因子について調らべた。

結果

各症例の最終観察時 JOA score は症例 1 から症例 4 までそれぞれ 75 点, 59 点, 63 点, 48 点であった (図 1).

術前と術後の屈曲角度の変化は 1 例で良好な可動域 改善が見られたが, 他は若干の改善があるのみであっ た（図2）。

JOA scoreの日常生活動作群の項目に基づき, 採 点を行い, 術前と術後の変化を調查した. 術後に 3 点 から 6 点, 平均 5 点の改善があり, 患者の満足度も高 かった（図 3，4）.

\section{症 例 供 覧}

【症例 1】:67 歳 女性（図 5)

\section{【主訴】：右肩関節痛}

【脱臼期間】 : 11 週

【現病歴】 : 転倒し受傷した. 直後より右肩に強い疼 痛と挙上困難あったが放置した，症状の軽隇ないため 受傷後 10 週で当科受診となった.

【画像所見】：単純 X 線で前方脱臼をみとめ, 大結節 部には不整像があった，CTではHill-Sack'slesion, Bankart-lesion を認めた。 また，肩関節造影では腱
板断裂も伴っていた.

【手術所見】：整復は容易であったが，外旋 30 度で脱 臼し, locking を認めた．前方の関節唇は破壊され， ほとんど残っていなかったが，関節面に著明な損傷は なかった，関節窩に $1 \mathrm{~cm} \times 1 \mathrm{~cm} \times 2.5 \mathrm{~cm}$ の骨移植を 行った.

【術後経過】 : 術後三角巾で固定し，2 日目より振り 子運動を開始した。術前屈曲は 20 度だったが, 3 週 間で 55 度と改善が見られ，最終的には 130 ·度まで可 能であった。

【症例 2】: 70歳 女性 (図 6)

【主訴】：右肩関節痛

【脱臼期間】 : 16 週

【現病歷】：転倒し受傷した，直ちに近医にて徒手整 復されたが挙上困難と疼痛が持続したため 2 カ月後当 科紹介受診となった.

【画像所見】：単純 $\mathrm{X}$ 線で前方脱臼をみとめ, 大結節 部には不整像があった. MRI, 関節造影では腱板断 裂の所見もあった.

【手術所見】：関節窩前下方の骨性成分の欠損, 骨頭 の扁平化がみられた．整復し， $1.2 \mathrm{~cm} \times 1 \mathrm{~cm} \times 2 \mathrm{~cm}$ の骨移植を行った.

【術後経過】：術後は屈曲 120 度, 内旋 90 度で胴体ギ プスを巻いた. 6 週目に単純 X 線で脱臼があったた 


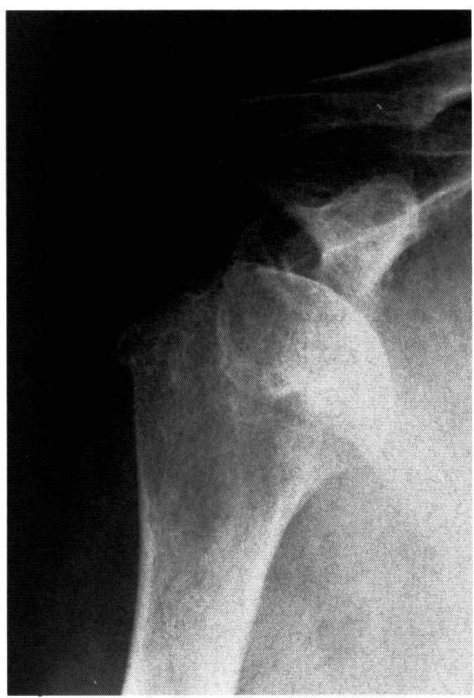

術 前

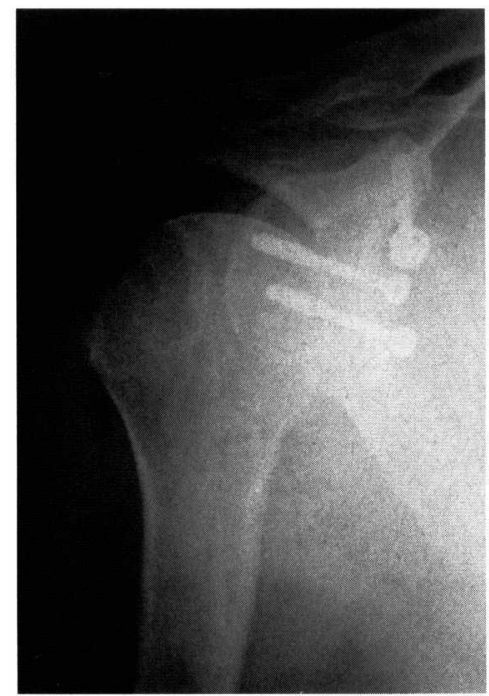

最終観察時

図 5 症例 $1: 67$ 歳, 女性.

前方脱臼をみとめ，大結節部には骨欠損がみられた。

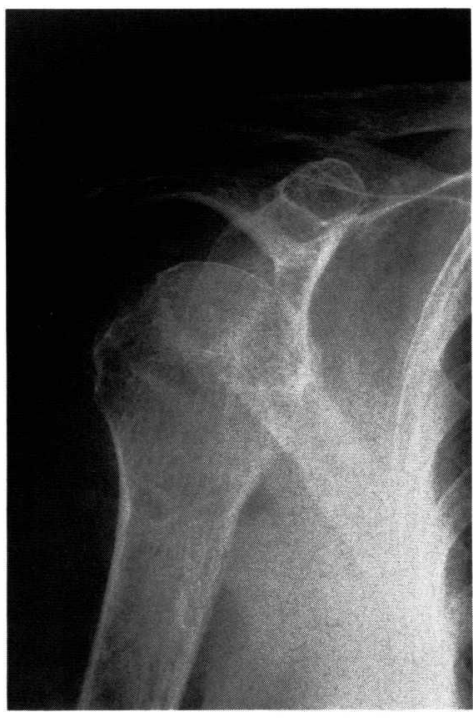

術 前

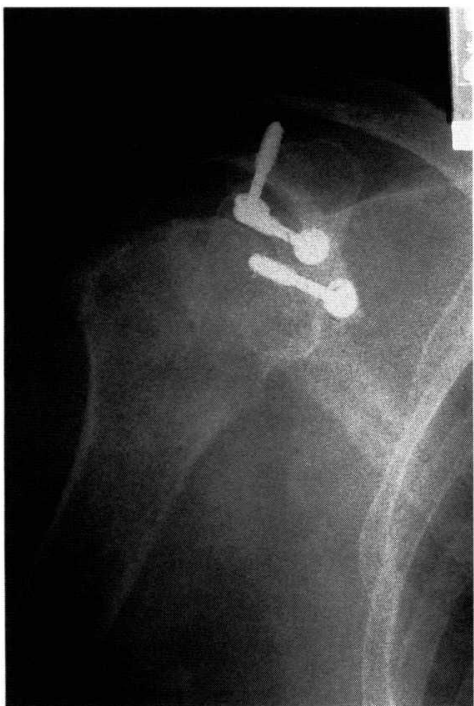

最終観察時

図 6 症例 2:70歳, 女性. 前方脱臼をみとめ, 大結節部には不整像がみられた。

め外転枕に変更したが, 改善無く、ロッキングを認め たため 9 週目に徒手整復および肩関節授動術を施行し た.この際上腕骨骨折を生じプレート固定を行った。 術後 4 年後脱臼はなかった.
【症例 3】: 37 歳 男性 (図 7)

【主訴】: 右肩関節痛

【脱臼期間】 $: 6$ 週

【現病歴】: 自殺を企図し崖から飛び降り受傷した。 


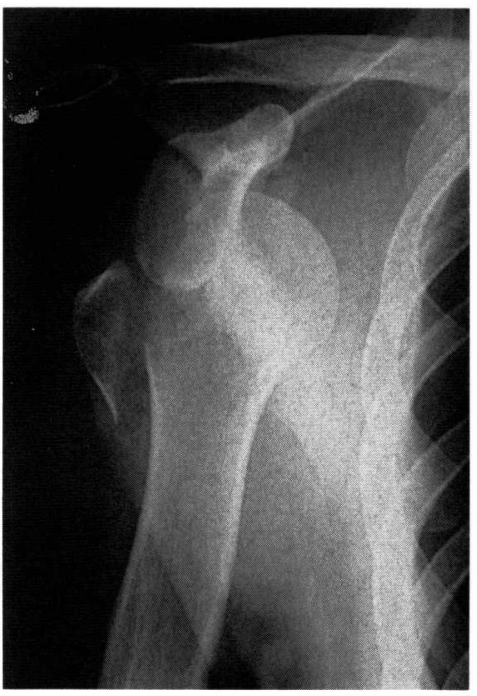

術 前

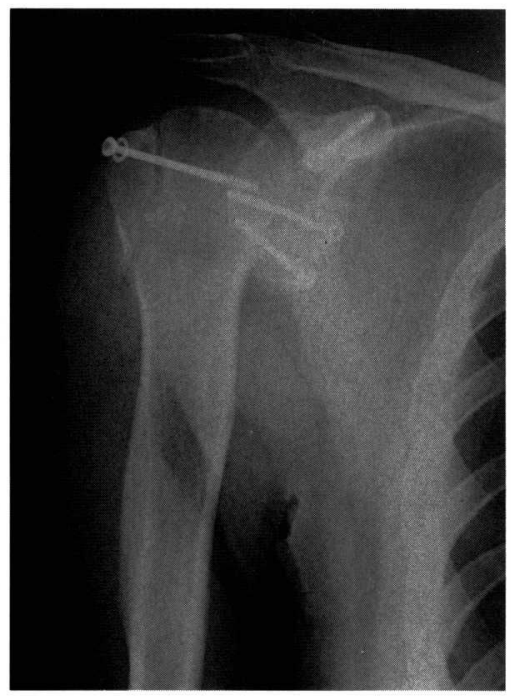

最終観察時

図 7 症例 $3: 37$ 歳, 男性.

骨頭は大結節骨折を伴い，関節窩の前方に完全に脱臼していた.

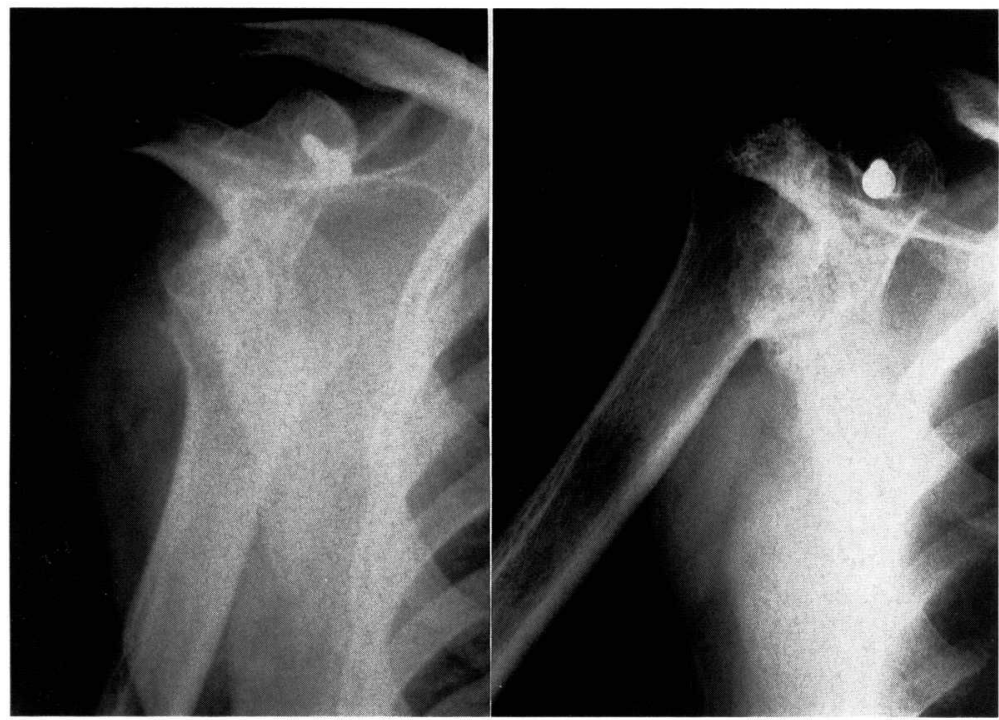

術 前

最終観察時

図 8 症例 $4: 30$ 歳, 男性.

TSR 後, 感染の徴候があり，抜去した。

近医に搬送され脱臼を指摘されたが治療を拒否し放置 した. 3 週後当科外来受診した. 既往に精神分裂病が あった。

【画像所見】：単純 X 線で骨頭は大結節骨折を伴い,
関節䆚の前方に完全に脱臼していた.

【手術所見】：前方の関節窩は破壊されていた。整復 し, $2 \mathrm{~cm} \times 2 \mathrm{~cm} \times 3 \mathrm{~cm}$ の骨移植と大結節の骨接合を 行った. 
表 1 各症例の後療法

\begin{tabular}{ccccc}
\hline \hline 症例 & 術後固定法 & 障害因子 & 振り子運動開始期 & 滑車運動開始期 \\
\hline 1 & 三角巾 & 無 & 2 日 & 13 日 \\
2 & $\begin{array}{c}\text { 胴体ギプス (初回術後) } \\
\text { 三角巾 (2 回目の術後) }\end{array}$ & $\begin{array}{c}\text { 再脱臼 } \\
\text { 上腕骨骨折 }\end{array}$ & 11 週 & 12 週 \\
3 & Velpeau 固定 & 精神分裂病 & 9 週 & 4 週 \\
\hline
\end{tabular}

【術後経過】：9 日目より振り子運動開始を行ったが， 精神科病棟入院中であったため病棟内で滑車や重鍾が つかえないことに加えて後療法に対する理解が低く， 効果的な運動療法はできなかった。

【症例 4】: 30 歳 男性 (図 8)

【主訴】 : 右肩挙上困難

【脱臼期間】: 56 週

【現病歷】: 交通事故で受傷した。 2 力月間意識消失 の状態にあった．前医で観血的整復術を受けたが整復 できず，約 1 年後に当科紹介となった。

【手術所見】：受傷後 1 年 8 週後に観血的整復術を試 みたが関節内の広範な破壊により整復でなかった， 16 週後に人工関節置換術を施行したが 5 日で脱臼し，徒 手整復を試みるも整復は得られず, その後感染の徴候 があったため抜去した。

\section{考察}

陳旧性肩関節脱臼に対しての治療法に関するは諸 家の報告は多く，その方法は大きく分けると観血的療 法 $^{2-13)(15) 16)}$ と保存療法 ${ }^{114)}$ に分けられる。本疾患の治療 では，後療法も重要であるが，それに関する報告は少 ない．現段階では，三角巾を用いて下垂位にする方法 とギプスを用いて挙上位に固定する方法が行われてい $3^{3-8) 131151166}$. 我々の術後固定法, 後療法開始時期など 後療法に関して（表 1)，三角巾で固定し，早期に振 り子運動を開始した症例 1 では成績は良かったが, ギ プスで挙上位にした症例 2 では悪かった。これはギプ ス内での脱臼の発見が遅れ，それに対する処置のため に後療法の開始も遅れたためと考えた。また，精神分 裂病を伴った症例 3 では滑車や重鍾等の運動器具が精 神科病棟では使用できないことと患者自身の後療法に 対する理解の低さのために効果的な後療法がほとんど できなかった。これらのことは陳旧性肩関節脱臼が治 療法のみではなく，後療法も重要であることを示して
いよう。すなわち，術中所見より再脱臼の恐れが低い と判断されれば, 三角巾などの簡単な固定を行い, 早 期に後療法を開始した方が良い結果が得られると考え られた。

本疾患が高齢者に多いこと, 運動時痛はあるが安静 時痛はなく，かつ非脱臼側でかなりの日常生活を行う ことができる場合には放置されたり対症療法に終始す ることがある。しかし，本疾患の主症状の 1 つである 運動時痛, 特に内旋時の疼痛を改善することは日常生 活で大切なことである. 今回の調查でも，術後日常生 活動作の改善がかなり見られたことは，たとえ可動域 改善はわずかでも観血的療法の有効性を示しているも のと言えよう。

$$
\text { ま と め }
$$

(1)陳旧性肩関節脱臼に対する観血的治療を行った 4 例の結果を調查検討した。

(2)術式として，関節窩形成術を 3 例，人工肩関置換 術を 1 例に行った。

(3)早期に後療法を開始できるような術後固定法が機 能獲得に有用であった。

(4)脱臼の整復により疼痛など自覚症状の軽減が得ら れ，ROM 改善は少なくても ADL の改善は期待でき ると考えた。

\section{参 考 文 献}

1）後藤康夫ほか：陳旧性肩関節前方脱臼の 3 例. 肩関節, $18: 337-343,1994$.

2）河野亨ほか：臼蓋形成術を行った陳旧性肩関節前方 脱臼の 2 例. 整·災害, $32: 1099-1103,1989$.

3）水野耕作ほか：関節窩骨折を伴った陳旧性肩関節脱臼 の 1 例. 肩関節, $5: 38-40,1981$.

4）仲川喜之ほか：肩関節陳旧性脱臼. 別冊整形外科，23： 8-14, 1993.

5）仲川喜之ほか：陳旧性肩関節脱臼の観血的治療につい て. 肩関節, $16: 73-78,1992$. 
6）中村隆二郎ほか：陳旧性肩関節前方脱臼 3 例の手術治 療経験. 東北整災紀要, $33: 159-162,1989$

7）西口雅彦ほか：陳旧性肩関節脱臼の観血的整復の治療 経験。整形外科と災害外科，42:268-269，1993.

8) Rowe, C. R.: Chronic unreduced dislocations of the shoulder. JBJS, 64-A, 4: 494-505, 1982.

9）菅原黎明ほか：陳旧性肩関節脱臼の治療経験。中部整 災誌, $29: 1845-1848,1986$.

10）菅原黎明ほか：陳旧性肩関節脱臼治療の検討。日整会 誌, $58: 117-120,1984$
11）寺脇 稔ほか：陳旧性肩関節脱臼の 4 例. 中部整災誌, $29: 1843-1844,1986$

12）植村忠一ほか：陳旧性の外傷性肩関節脱臼の手術経験. 整形外科と災害外科, $30: 809-812,1982$.

13）山本龍二 : 陳旧性肩関節前方脱臼は無理に整復しなく てもよい. 別冊整形外科, $23: 36-42,1993$.

14）山本龍二ほか：肩腱板断裂修復後に見過ごされた陳旧 性肩関節前方脱臼の1例．関東整災外会誌，17:172-175, 1986. 